\title{
$\mathrm{BM}$ 미생물제제를 이용한 크루즈선 오·폐수 처리
}

\author{
이언승*• † 김인수 \\ *경성대학교, † 한국해양대학교 토목환경공학부 교수
}

\section{Shipboard sewage treatment by SBR process with BM}

\author{
Eon-Sung Lee* $+{ }^{+}$In-Soo Kim \\ *Analysis center of Kyungsung University, Pusan 608-736, Korea \\ † Division of Civil and Environment, National Korea Maritime University, Pusan 606-791, Korea
}

\begin{abstract}
요 약 : 본 연구는 크루즈선에서 발생하는 오·폐수의 생물학적 처리시 야기될 수 있는 악취 문제를 해결하기 위하여 SBR공정에 유효미 생물을 주입하여 Lab scale 실험을 수행하였다. 악취물질의 저감 정도와 크루즈선이라는 특수 환경과의 접목성을 검토한 결과 유효미생물의 주입은 선박환경에 매우 적합한 공정으로 평가되었다. 기존의 활성슬러지에 유효미생물의 주입함으로써 슬러지 내 미생물의 다양성과 높은 개체수를 확보할 수 있었으며, 미생물 간의 우점종도 악취처리에 유리한 미생물종으로 전환되는 것을 확인할 수 있었다. 또한 이로 인하여 악 취물질의 악취 강도도 20 배 이상 낮출 수 있는 것으로 확인되었다.
\end{abstract}

핵심용어 : 연속회분식 반응조, 유효미생물, 크루즈선, 선박 오수, 악취

Abstract : Lab scale experiment study was carried out for biological treatment process development in cruise. SBR(Sequence Batch Reactor) process with BM(Beneficial Microorganisms) was investigated for practical application on shipboard sewage treatment. From the results it was suggested that SBR process with BM might be a suitable process for cruise sewage treatment in terms of decrease in odorous compounds, maintenance of useful microorganisms and creating special environmental conditions. By adding BM to SBR system, odor unit of sulfur compounds was about 20 times reduced.

Key words : SBR, BM, cruise, shipboard sewage, odorous compounds

\section{1. 서 론}

세계적으로 삶의 질이 향상됨에 따라 선박이 고급화되고 여 행객의 증가로 대형 여객선이 출현하게 되어, 이로 인한 오폐 수 발생량이 증가하여 해양오염의 방지 및 통제의 필요성이 제기되어 왔다. 이에 $\mathrm{IMO}$ (International Maritime Organization) 는 선박에서 발생되는 오수의 관리와 처리를 위한 MARPOL 73/78의 부속서 IV를 2003년 9월 27일부터 국제적으로 발효하 였으며, 국내에서도 2004년 협약을 발효하였다.

선박의 오수처리는 선상에서 오수를 처리하여 배출해야 한 다는 점에서 육상에서 오수처리시 고려되어야 하는 요건외에 도 선박이라는 특수한 환경에서 요구되는 요건들이 추가적으 로 충족되어야 한다. 선박에는 많은 기기들이 한정된 공간에 밀집되어 있기 때문에 우선 오수처리장치의 크기가 최소한으 로 작아야 하고, 선박용 오수처리장치는 전문가가 아닌 선원 들에 의해 운영되어야 하므로 장치는 간단하고 운전의 자동화 가 필수적이다. 이러한 면에서 SBR(Sequence Batch Reactor) 공법은 선박환경에 매우 적합한 공정으로 판단된다.
한편 $\mathrm{SBR}$ 공법과 같은 생물학적 처리 방법으로 오수를 처 리할 때 야기되는 대표적인 문제로는 원수와 슬러지로부터 발 생되는 악취 문제를 들 수 있다. 크루즈 선박과 같은 여가를 위한 대형선박에서 만일의 경우 악취 문제가 발생되어 선내로 악취물질이 유입된다면 승선객들이 느끼는 불쾌감은 숫자로 산정할 수 없을 만큼 클 것이다. 또한 상선이나 화물선 등의 여객선이 아닌 선박에서도 생물학적 처리로 기인한 악취 문제 가 발생한다면 선원들의 대처 능력은 극히 미비할 것으로 예 상된다.

$\mathrm{BM}$ (Beneficial Microorganisms)의 공통적인 특징은 유기 물을 분해하면서 항산화물질을 생성하는 것으로 부패 및 악 취를 억제 - 방지하고 오수처리에 있어서도 정화 효과가 있는 것으로 알려져 있다. 또한 생물학적 수처리에 적용할 경우 기존의 시설에 여타의 시설 추가 없이 기존의 활성슬러지에 $\mathrm{BM}$ 제제를 주입하는 것만으로 정화효과를 얻을 수 있어 선 박과 같은 특수한 환경에서의 적용이 매우 용이할 것으로 판 단된다.

이에 본 연구에서는 선박환경에 적합한 $\mathrm{SBR}$ 공정을 도입하

* 연회원, les@ks.ac.kr 051)663-5480

† 연회원, iskim@hhu.ac.kr 051)410-4416 
고 $\mathrm{BM}$ 미생물 제제를 추가 주입하여 선박에서의 악취 물질 제거와 안정적인 효율을 확보하고자 기초 실험을 수행하였다. 이를 위해 $\mathrm{BM}$ 제제 주입 전 후의 미생물을 비교 관찰하고 오 수처리 시 발생할 수 있는 황계열 악취 성분을 정량 분석하여 $\mathrm{BM}$ 제제의 악취 저감 효과를 확인하였다.

\section{2. 실험장치 및 실험방법}

\section{1 실험장치}

본 연구에서 선박오수의 생물학적 처리 시 발생될 수 있는 악취 문제를 제어하고자 $\mathrm{BM}$ 의 적용을 검토하였다. 이를 위하 여 기존의 $\mathrm{SBR}$ 프로세스를 활성슬러지로 운영하는 경우를 run-1, 활성슬러지에 $\mathrm{BM}$ 을 추가 주입하여 운영한 경우를 run-2로 하여 결과를 비교 관찰하였으며, Lab scale로 제작한 실험장치의 개략도를 Fig. 1에 도시하였다.

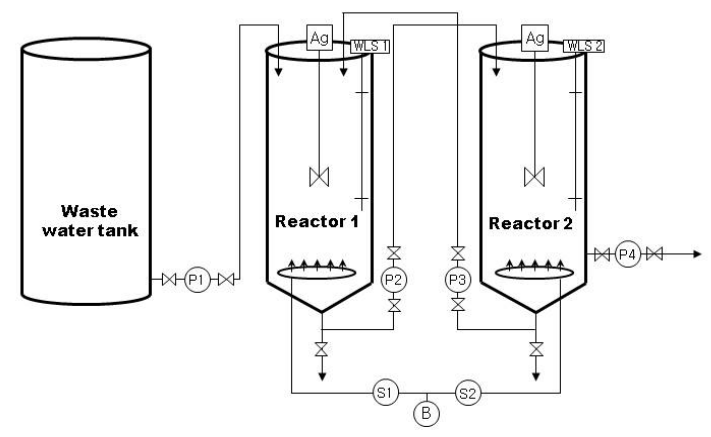

Fig. 1 Schematic diagram of SBR system

Lab scale 실험 장치는 운영시의 상태 관찰을 위하여 $10 \mathrm{~mm}$ 의 투명 아크릴 재질로 처리용량 $200 \ell / \mathrm{d}$ 로 제작하였다. SBR 반응조는 원형조로 전체 용적은 $146 \ell(\mathrm{D}=0.5 \mathrm{~m})$ 로 1 cycle당 50 $\ell$ 로 운영하여 폭기에 따른 여유 공간을 두었다.

생물학적 처리를 위한 SBR 반응조의 미생물은 Bacillus $s p$. 을 우점종으로 하여 연구하였으며, 초기 Bacillus sp. 의 우점 화를 위해 $\mathrm{B} 3$ 공법으로 운전하고 있는 $\mathrm{P}-$ 분뇨처리장(부산 감 전동)의 폭기조 내 농축 슬러지를 채취하여 사용하였다. 슬러 지는 체를 이용한 협작물 제거와 수 차례의 세척과정을 거친 후 10 일간 인공 폐수를 이용한 기질 적응기간을 두어 공정에 투입하였으며, MLSS 농도는 약 $3000 \mathrm{mg} / \ell$ 정도를 유지하여 운전하였다.

복합미생물을 이용한 선박오수 처리의 적용 가능성을 검토 하기 위하여 다른 조건들은 동일하게 유지하고 $\mathrm{BM}$ 제제를 주 입하면서 반응기를 운영하여 그 결과를 비교하였다. $\mathrm{BM}$ 제제 는 원액(B사, BM-S-1)을 구매하여 50배 희석한 후 사용하였 으며, 초기 미생물 식종시는 슬러지 부피의 $10 \%$ 에 해당하는 양을 3 일간 주입하고, 이후 운영시는 유입수 부피의 $1 \%$ 에 해 당하는 양을 유입수에 섞어 주입하였다.

각 공정 내 미생물의 생장 환경 확인을 위하여 $\mathrm{pH}, \mathrm{DO}$, 온 도, $\mathrm{ORP}, \mathrm{SV}_{30}$ 을 지속적으로 측정하였고, 슬러지의 현미경 관
찰과 생균수 확인을 통하여 미생물 생장 상태의 정상 여부를 판단하였다.

\section{2 실험방법}

1) 시료의 성상 및 반응조 운전방법

반응조 가동에 사용한 시료는 한국해양대학교 학생기숙사 에서 발생되는 오수를 이용하여 선박에서 배출되는 오수와 거 의 유사한 실제 시료로 가동하여 현장 실험과 가까운 데이터 를 얻을 수 있도록 하였다. 유입된 오수의 특성은 Table 1 과 같다.

Table 1 Characteristics of influent

\begin{tabular}{|c|c|c|}
\hline \multirow{2}{*}{ Parameter } & \multicolumn{2}{|c|}{ Concentration $(\mathrm{mg} / \ell)$} \\
\cline { 2 - 3 } & Range & Mean \\
\hline BOD $_{5}$ & $100 \sim 200$ & 160 \\
\hline COD $_{\mathrm{Cr}}$ & $200 \sim 270$ & 230 \\
\hline T-N & $20 \sim 95$ & 50 \\
\hline T-P & $5 \sim 15$ & 7 \\
\hline TSS & $150 \sim 350$ & 260 \\
\hline Thermotolerant Coliform $($ cell $/ \mathrm{m} \ell)$ & $4 \sim 5 \times 10^{4}$ & $4.5 \times 10^{4}$ \\
\hline
\end{tabular}

반응기는 2010년 1월부터 2010년 3월까지 약 3개월 동안 연 속 운전하였으며, 수온은 $20^{\circ} \mathrm{C}$ 로 유지하고, DO $2.0 \sim 5.0 \mathrm{mg} /$ $\ell$, pH $6.5 \sim 7.5, \mathrm{~F} / \mathrm{M}$ 비 $0.15 \mathrm{~kg} \cdot \mathrm{BOD} / \mathrm{kg} \cdot \mathrm{MLVSS} \cdot \mathrm{DAY}$ 로 운전하였다.

2) 반응기 내 미생물 관찰

반응조의 슬러지는 현미경 관찰과 $\mathrm{MLSS}, \mathrm{SV}_{30}$, 생균수 확 인을 통하여 미생물 생장 상태의 정상여부를 판단하였다.

우선 실험에 사용된 활성슬러지와 $\mathrm{BM}$ 제제 식종 슬러지의 미생물 조성을 조사하기 위하여 반응기 내 슬러지를 채취하여 순수 배양하였다. 순수 배양한 미생물은 미생물자동동정기 (VITEK2 Compact, Biomeroeux)로 동정하거나 16S rDNA법 으로 분석하였다. 또한 $\mathrm{BM}$ 제제의 주입에 따른 반응조 내의 미생물 군집 구조의 변화를 분석하기 위해 PCR-DGGE 기법 을 이용하였다.

\section{3) 악취물질 분석방법}

악취 성분은 유출수와 반응기 운영 시의 슬러지를 대상으로 정성 및 정량 분석을 수행하였다. 유출수 정성 분석은 황계열 및 질소계열 악취 성분을 중심으로 수행하였고, 유출수의 정 성 분석 결과와 하수처리장의 악취 성분을 참고하여 시료에 함유되어 있을 것으로 추정되는 황계열 지정악취물질을 중심 으로 정량 분석 수행하여 $\mathrm{BM}$ 제제 주입에 따른 악취물질 저 감 효과를 확인하였다. 
우선 악취성분 감소 여부를 예측하기 위하여 반응기 내 황 산이온 $\left(\mathrm{SO}_{4}^{2-}\right)$ 을 측정하여 생물학적 반응에 의한 산화 효과를 확인하였다. 황산이온 $\left(\mathrm{SO}_{4}{ }^{2-}\right)$ 은 IC(Metrohm, 709METALFREE) 를 이용하여 측정하였다.

유출수에 잔존하는 악취물질 성분 조사는 PURGE \& $\mathrm{TRAP}$ 법으로 전처리하고 $\mathrm{GC} / \mathrm{MSD}$ 를 이용하여 정성 분석하 였다. 슬러지 내 악취물질 성분은 고상미세추출법(HS-SPME, Headspace Solid-phase Microextraction)을 이용하여 추출하 고 $\mathrm{GC} / \mathrm{MS} \mathrm{SIM}$ (Selected ion monitoring) mode로 정량하였 다. 시료에 함유되어 있을 것으로 추정되는 황계열 지정악취 물질인 Hydrogen sulfide, Methyl mercaptan, Dimethyl sulfide, Dimethyl disulfide을 대상으로 하여 분석을 진행하였 으며, 분석에 이용된 기기 사양 및 추출조건, $\mathrm{GC}$ 조건, 정량을 위한 Selected ions들은 Table 2와 같다.

Table 2 Analysis conditions for sulfur compounds

\begin{tabular}{|c|c|l|}
\hline $\begin{array}{c}\text { Analysis } \\
\text { Equipment }\end{array}$ & GC-MSD, Agilent $6890 / 5973 \mathrm{~N}$ \\
\hline Extraction & \multicolumn{2}{|c|}{$10 \mathrm{~min}$ at $40^{\circ} \mathrm{C}$} \\
\hline Desorption & \multicolumn{2}{|c|}{3 min at $250^{\circ} \mathrm{C}$} \\
\hline \multirow{2}{*}{ Inlet } & $220^{\circ} \mathrm{C}$, splitless injection mode \\
\hline \multirow{2}{*}{ Column } & $\mathrm{HP} 5 \mathrm{~ms}(60 \mathrm{~m} \times 0.25 \mathrm{~mm} \times 0.25 \mu \mathrm{m}), 1 \mathrm{~m} \ell / \mathrm{min}$ \\
\hline \multirow{2}{*}{ Oven } & $35^{\circ} \mathrm{C}$ (hold for $\left.10 \mathrm{~min}\right): 5{ }^{\circ} \mathrm{C} / \mathrm{min}$ to \\
\hline \multirow{3}{*}{ Selected Ion } & Hydrogen sulfide & 34 (Mass ion), 33, 36 \\
\cline { 2 - 3 } & Methyl mercaptan & 47 (Mass ion), 48, 45 \\
\cline { 2 - 3 } & Dimethyl sulfide & 62 (Mass ion), 47, 45 \\
\cline { 2 - 3 } & Dimethyl disulfide & 94 (Mass ion), 79, 45 \\
\hline
\end{tabular}

유입수 및 유출수의 특성을 파악하기 위해 반응기 운영기간 동안 유기 성분 조사는 O.I사의 $\mathrm{VOCARB}^{\mathrm{TM}} \mathrm{Trap}$ 을 이용하여 Sample Concentrator로 농축한 시료를 GC/MSD SCAN mode로 관찰하였다.

\section{3. 실험결과 및 고찰}

\section{1 생물반응기 내 미생물 관찰}

활성슬러지를 이용한 run-1에서 공정 내 반응조의 미생물 은 Bacillus sp.로 우점화되어 있었으며 분리 배양하여 미생물 자동동정기(VITEK2 Compact, Biomeroeux)로 동정하고 생화 학 테스트를 거친 결과 B.subtilis, B.cereus, B.valismortis, B.megaterium 등으로 동정되었다.

사용된 $\mathrm{BM}$ 제제(B사, $\mathrm{BM}-\mathrm{S}-1)$ 는 Pyrosequencing 결과 130종의 다양한 세균 및 효모로 구성되어 있었으며 Table 3에 동정된 주요 미생물과 그 분포를 나타내었다.
Table 3 Identification of microorganisms in BM by pyrosequencing

\begin{tabular}{|l|c|}
\hline \multicolumn{1}{|c|}{ Microorganism } & Distribution(\%) \\
\hline Prevotellaceae_uc_s & 22.2 \\
\hline Lactobacillus_uc & 17.7 \\
\hline Lactobacillus parabuchneri & 6.9 \\
\hline Lactobacillaceae_uc_s & 6.5 \\
\hline Lactobacillus paracasei & 5.8 \\
\hline Lactobacillus parafarraginis & 4.3 \\
\hline Lactobacillus camelliae & 3.0 \\
\hline Lactobacillus manihotivorans & 2.4 \\
\hline Acetobacter lovaniensis & 2.3 \\
\hline Lactobacillus collinoides & 2.2 \\
\hline Lactobacillus vini & 2.0 \\
\hline Lactobacillus hilgardii & 1.8 \\
\hline Lactobacillus pentosus & 1.7 \\
\hline Lactobacillus rapi & 1.5 \\
\hline Lactobacillus pantheris & 1.3 \\
\hline Ethanoligenens_uc_s & 1.2 \\
\hline Veillonellaceae_uc_s & 1.2 \\
\hline Lactobacillus similis & 1.2 \\
\hline Lactobacillus harbinensis & 1.0 \\
\hline Rhodospirillales_uc_s & 0.5 \\
\hline Others & 13.8 \\
\hline & 100.0 \\
\hline Total & \\
\hline & \\
\hline
\end{tabular}

Note) uc_s : Unclassified species

순수 분리된 각 미생물 중 현미경 관찰을 통해 효모로 추정 된 미생물을 따로 선택하여 미생물 자동동정기로 자동 동정하 고 생화학테스트를 거친 결과 99\% Homology로 Candida boidinii, Saccharomyces cerevisiae로 동정되었다.

$\mathrm{BM}$ 종균에서 동정된 유산균 균주들은 불용성 염을 가용화 하는 것으로 보고되고 있으며, 동정된 Rhodospirillales 종은 광합성세균으로 $\mathrm{H}_{2} \mathrm{~S}$ 등의 악취 처리에 효과가 있는 것으로 보고되고 있다(이, 2004). 또한 동정된 B.subtilis과 Saccharomyces cerevisiae는 GRAS(Generally recognised as safe)로 분류되는 미생물로 생균제 및 환경개선제의 균주로 폭넓게 사용되고 있으며, 연구결과에 의하면 대장균의 증식 억제에 효과가 있는 것으로 보고되고 있다(윤 등, 2009). 동정 된 메탄올 자화성 효모(Methanol -assimilatin yeast)인 Candida boidinii는 암모늄, 질산염, 아질산염, 유기질소원, 요 소, 아미노산 형태의 질소원을 모두 이용할 수 있는 것으로 보 고되고 있어 영양염류의 제거에 매우 유리하게 작용할 수 있 을 것으로 예상된다. 또한 증식속도가 빠르고 생장환경이 넓 으며 효소생성능력이 높아 매우 유용한 미생물로 보고되고 있 으며 페놀화합물의 분해능 또한 높은 것으로 알려져 있다 (Halah et al, 2007). 
이에 동정된 다양한 균들이 서로 공존공생하며 시너지 효과 를 나타내면서 run-2에서 악취물질을 비롯한 오염물질의 제 거율 향상에 복합적으로 기여하였을 것으로 사료된다.

Pour plate method로 측정한 생균수는 run-1의 SBR 반응 조에서는 $3.2 \times 10^{6 \sim} 1.2 \times 10^{7} \mathrm{CFU} / \mathrm{ml}$ 으로 나타났으며, run-2의 $\mathrm{BM}$ 제제 식종 시는 $8.7 \times 10^{7} 7.2 \times 10^{8} \mathrm{CFU} / \mathrm{ml}$ 으로 나타났다.

$\mathrm{BM}$ 제제를 주입한 경우 예상대로 미생물종의 다양성과 높 은 미생물 개체수를 보였으며, 이러한 미생물의 조성의 차이 에 기인하여 안정적인 수처리 효율을 확보할 수 있었던 것으 로 판단된다.

\subsection{PCR-DGGE 기법에 의한 미생물 군집 분석 결과}

Nested PCR 결과로 얻어진 2차 PCR 산물로 DGGE 분석을 수행한 결과 $\mathrm{BM}$ 제제 주입 전후의 각 Lane에서 Band 강도 차이를 관측할 수 있었으며, 관측 결과로부터 $\mathrm{BM}$ 제제 주입 전후의 우점종 변화를 확인할 수 있었다. 미생물 군집 구조 분 석 결과 Fig. 2와 같이 $\mathrm{BM}$ 제제 주입 전인 $\mathrm{L} 1$ 및 $\mathrm{L} 2$ 에서는 $\mathrm{Band} 2$ 가 우점종으로 나타났으나, L3 및 $\mathrm{L} 4$ 에서는 $\mathrm{BM}$ 제제 주입으로 $\mathrm{Band8}$ 및 $\mathrm{Band11}$ 로 우점종이 변화된 것을 확인할 수 있었다.

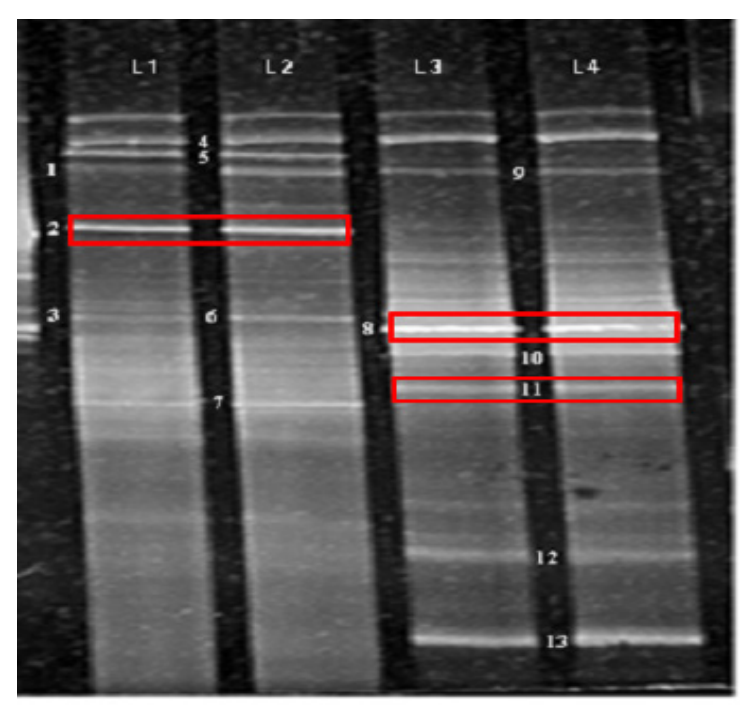

Fig. 2 Analysis on the microbial community structures using PCR-DGGE method(L1, L2; conventional activated sludge, L3, L3; BM added sludge).

이에 $\mathrm{DGGE}$ 결과에서 강도 차이가 있는 $\mathrm{Band}$ 를 주형으로 하여 증폭 후 염기서열 분석을 의뢰하였다. 동정 결과 $\mathrm{BM}$ 제 제 주입 전의 경우는 Clostridia sp.(Band2)가 우점종이었으 나, $\mathrm{BM}$ 제제 주입 후는 Sphingomonas sp.(Band8 및 Band11) 가 우점종으로 나타났다. 따라서 반응기의 환경이 혐기성조건 에서 호기성미생물의 증식에 유리한 방향으로 전환된 것을 확 인할 수 있었다. 또한, $\mathrm{BM}$ 제제 주입 후 우점종으로 나타난 Sphingomonas sp.는 난분해성 물질 분해에 유효한 미생물로 써 이러한 우점종의 변화는 유해물질의 분해특성 또한 변화시
킨 것으로 예측된다.

\section{3 악취물질 제거 효율 비교}

반응기 운전 기간 동안 $\mathrm{BM}$ 제제를 식종하지 않은 슬러지로 반응기를 가동하였을 경우 반응기 운영 시 악취를 감지할 수 있었으며 유출수에서도 미세한 취기를 느낄 수 있었다. 반면 $\mathrm{BM}$ 제제로 운영 시는 시료 주입과 주입 후 매우 단시간 동안 만 미미한 악취를 감지할 수 있었는데 이는 유입수 내 존재하 는 악취물질에 기인된 것으로 사료되며, $\mathrm{BM}$ 제제로 장치 운 영시 유출수에서는 악취를 전혀 감지할 수 없었다. GC/MSD 를 이용한 유출수의 기기 분석 결과에서도 run-1에서는 황계 열 화합물이 검출된 반면 run-2에서는 황계열 악취물질이 전 혀 검출되지 않아 동일한 결과가 도출되었다.

이에 $\mathrm{BM}$ 제제 주입 전후의 물질 거동을 관측하여 악취물질 저감 특성을 관찰하였다. 우선 본 실험에서는 폭기시 반응기 내 존재하는 황산이온 $\left(\mathrm{SO}_{4}{ }^{2-}\right)$ 을 측정하여 황화합물의 산화 효 과를 확인하였다. 폭기 시간에 따른 반응기 내 황산이온 $\left(\mathrm{SO}_{4}{ }^{2-}\right)$ 의 변화를 Fig. 3에 나타내었다.

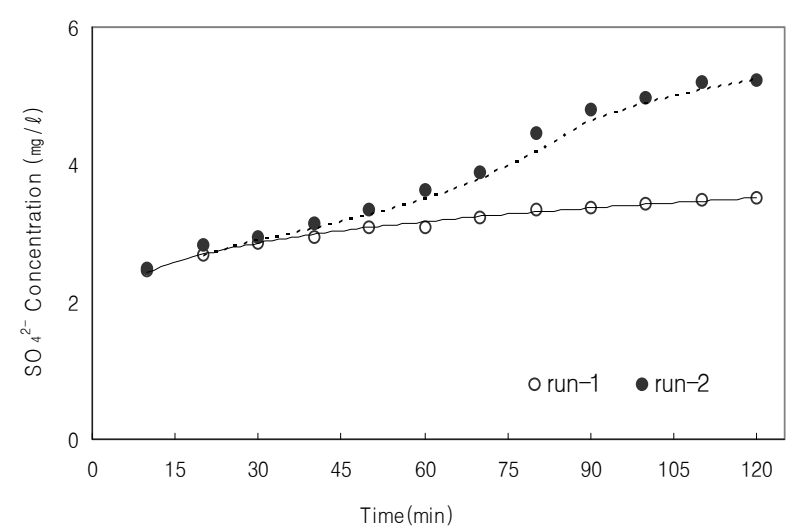

Fig. 3 Change in $\mathrm{SO}_{4}^{2-}$ in bioreactor.

Fig. 3과 같이 황산이온의 농도는 폭기시간이 증가함에 따 라 증가하는 것으로 관찰되었다. run-1과 2의 운전조건에서는 초기 폭기 30분까지는 큰 차이를 보이지 않았으나 폭기 종료 후 최종 농도는 run-2에서 더 높은 것으로 나타났다. 이러한 결과로부터 $\mathrm{BM}$ 제제에 의한 생물학적 산화가 더 많이 이루어 지는 것을 유추할 수 있었으며, 악취물질의 제어면에서 복합 미생물군집체인 $\mathrm{BM}$ 제제를 이용한 처리가 매우 유리함을 예 측할 수 있었다.

Purge \& Trap을 이용한 GC/MSD Scan mode로 분석한 결 과 유입수에서는 암모니아와 아민류, 휘발성 유기산, 황계열의 악취물질 등이 검출되었다.

유출수의 경우 run- 1 에서는 황계열 유기화합물이 검출된 반면 $\mathrm{BM}$ 제제를 주입한 run-2에서는 관련 화합물은 검출되 지 않아 두 유출수의 황계열 악취물질에 대한 검출 결과는 매 우 대조적이었다. 유출수 분석 결과 비점이 낮은 $\mathrm{H}_{2} \mathrm{~S}$ 나 $\mathrm{CH}_{3} \mathrm{SH}$ 등의 황화합물은 run-1과 run-2에서 모두에서 검출되 
지 않았다.

$\mathrm{H}_{2} \mathrm{~S}$ 나 $\mathrm{CH}_{3} \mathrm{SH}$ 등은 산소 및 물과 반응하여 $\mathrm{O}_{2} \cdot, \mathrm{H}_{2} \mathrm{O} \cdot$ $\mathrm{H}$ - 등의 라디칼을 생성하여 Methylsulfide로 전환되고, 그 다음 Methyltrisulfide, Methyltetrasulfide 등의 저비점 성분 으로 변환되며, 냄새가 적은 성분인 Dimethyldisulfide로 전 환되거나 산화반응의 촉진으로 Methylsulfonicacid로 전환 되는 복잡한 경로를 갖는다. 유출수의 황계열 악취물질 분 석결과 run-1에서는 Dimethyldisulfide가 10회 중 6회, Dimethyltrisulfide가 4회 검출되었으며, 이는 미처리 하수에서 발생할 수 있는 냄새 성분이 변환되어 생성된 화합물로 판단 된다.

질소계 악취물질의 경우 run-1과 run-2의 유출수에서는 소 량의 암모니아만이 검출되었다. 유입수 성분에서는 암모니아 와 함께 디메틸아민과 같은 아민류의 악취 성분도 검출되었으 나 run-1과 run-2의 유출수에서는 아민류의 악취 성분은 모 두 검출되지 않았다.

아민류의 악취물질은 $\mathrm{pH}$ 가 높을 경우 문제가 되는 것으 로 알려져 있으며, TMA(Trimethylamine)의 경우 $\mathrm{pH}$ 가 10 이상일 때 악취의 문제를 나타내는 것으로 알려져 있 다. 본 반응기 운영기간 동안 $\mathrm{pH}$ 는 6.5 에서 7.5 범위가 유 지되었으며, 아민류의 악취물질은 유입수에서는 검출되었 으나 유출수에서는 검출되지 않았고, 생물학적 처리를 통 해 분해되어 암모니아의 형태로만 검출되었다. 암모니아의 경우 최소 감지농도는 $0.1 \mathrm{ppm}$ 으로 아민류에 비해 취기 한 계가 높으며, 황계열 악취물질에 비해서는 거의 200 1,000 배 이상 높다. 이러한 연유로 본 반응기 운영기간 동 안 악취에 관련된 문제는 황화합물에 기인하는 것이 대부 분일 것으로 사료된다.

유출수의 황화합물 검출 결과로부터 $\mathrm{BM}$ 제제에 의한 악취 물질 저감능력을 확인하였으며, 이에 $\mathrm{BM}$ 제제 주입에 따른 악취성분의 저감 정도를 관측하기 위하여 $\mathrm{BM}$ 제제를 주입하 지 않은 슬러지와 $\mathrm{BM}$ 제제를 3일간 주입한 슬러지의 황계열 지정악취물질을 정량 분석하였다.

8회에 걸쳐 분석한 황계열 악취물질의 검출 결과를 Fig. 4 에 나타내었다. $\mathrm{H}_{2} \mathrm{~S}$ 와 $\mathrm{CH}_{3} \mathrm{SH}$ 의 경우 두 시료에서 8회 모두 검출되었으나 그 검출 농도는 $\mathrm{BM}$ 제제 주입 시 매우 낮게 나 타났다. $\left(\mathrm{CH}_{3}\right)_{2} \mathrm{SH}$ 와 $\left(\mathrm{CH}_{3}\right)_{2} \mathrm{~S}_{2}$ 의 경우 활성슬러지로 운영 시 각각 3 회, 2 회 검출되었으며, $\mathrm{BM}$ 제제 주입 후는 검출되지 않 았다.

$\left(\mathrm{CH}_{3}\right)_{2} \mathrm{SH},\left(\mathrm{CH}_{3}\right)_{2} \mathrm{~S}_{2}$ 등의 분자량이 높은 황계열 악취물질은 우선 $\mathrm{CH}_{3} \mathrm{SH}$ 으로 분해되고, $\mathrm{H}_{2} \mathrm{~S}$ 형태로 전환되는 생분해 과정 을 거치며 생물학적으로 제거되는 것으로 알려져 있다. $\mathrm{H}_{2} \mathrm{~S}$ 와 $\mathrm{CH}_{3} \mathrm{SH}$ 보다 비교적 안정한 $\left(\mathrm{CH}_{3}\right)_{2} \mathrm{SH},\left(\mathrm{CH}_{3}\right)_{2} \mathrm{~S}_{2}$ 의 검출은 황 계열 악취성분이 충분히 산화되지 않고 미처리된 것으로 유출 수에서도 검출된 성분으로 유출수의 악취 문제에도 영향이 미 친 것으로 판단된다. 또한 $\mathrm{BM}$ 제제 주입 후 $\left(\mathrm{CH}_{3}\right)_{2} \mathrm{SH}$, $\left(\mathrm{CH}_{3}\right)_{2} \mathrm{~S}_{2}$ 는 검출되지 않은 것으로 미루어 $\mathrm{BM}$ 제제에 의한 생 분해가 이루어진 것으로 판단된다. 활성슬러지로 운영 시도
$\left(\mathrm{CH}_{3}\right)_{2} \mathrm{SH}$,와 $\left(\mathrm{CH}_{3}\right)_{2} \mathrm{~S}_{2}$ 의 검출 농도는 $\mathrm{H}_{2} \mathrm{~S}$ 와 $\mathrm{CH}_{3} \mathrm{SH}$ 농도에 비해서는 매우 미량이었으나 검출 시는 최소감지농도(Odor threshold)보다는 높은 값을 나타내어 장치 운영시 발생한 악 취에 복합적으로 기여했을 것으로 사료된다.
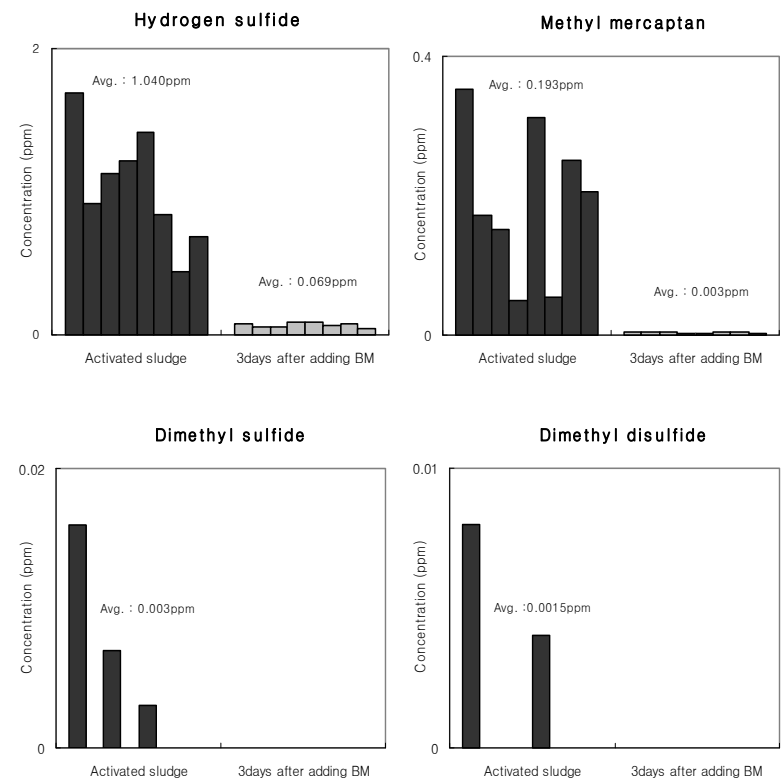

Fig. 4 Comparison of specific odors between conventional activated sludge and 3 days after adding BM.

정량분석 결과 $\mathrm{H}_{2} \mathrm{~S}$ 와 $\mathrm{CH}_{3} \mathrm{SH}$ 의 초기 농도 값에 관계없이 $\mathrm{BM}$ 제제에 의해 일정 농도까지 농도가 낮아지는 것을 확인할 수 있었다. 본 실험에서는 50 배 희석된 $\mathrm{BM}$ 제제를 슬러지의 $10 \%$ 용량으로 3 일간 주입하여 위와 같은 효과를 확인하였으 며 $\mathrm{BM}$ 제제의 주입 비율을 조절하면 더 높은 효과를 얻을 수 있을 것으로 판단된다.

황계열 악취물질의 농도를 각각의 취기한계로 나누어 각 물 질의 Odor index를 산정하여 각 화합물의 상대적인 악취기여 도를 비교하였다. $\mathrm{BM}$ 제제 주입에 따른 황 계열 악취물질에 대한 전체적인 저감 정도는 다음과 같이 각 물질의 Odor index의 산술합을 계산하여 Odor unit로 비교하였으며, Table 4에 그 결과를 나타내었다.

$\mathrm{BM}$ 제제 주입 시 악취강도는 Odor unit를 기준으로 20 배 이상 낮게 나타났다. Odor index 기준으로 $\mathrm{H}_{2} \mathrm{~S}$ 와 $\mathrm{CH}_{3} \mathrm{SH}$ 의 황계열 악취 기여도가 대부분인 것으로 나타났으 며, $\mathrm{BM}$ 제제 주입 시 $\mathrm{H}_{2} \mathrm{~S}$ 에 의한 기여도는 $52.3 \%$ 에서 $75.1 \%$ 로 상승하였고 $\mathrm{CH}_{3} \mathrm{SH}$ 에 의한 기여도는 $46.1 \%$ 에서 $24.9 \%$ 로 나타나 생분해가 진행되고 있음을 관찰할 수 있었 다. $\mathrm{BM}$ 제제 주입 3일 후 각각의 Odor index가 매우 낮아 진 점 이외에도 악취물질의 특성상 초기 농도 편차가 매우 컸음에도 불구하고 거의 일정한 값으로 낮아져 안정적인 저 감 효과를 나타냈다. 
Table 4 Odor index and odor threshold for target compounds

\begin{tabular}{|c|c|c|c|}
\hline & \multirow{2}{*}{$\begin{array}{c}\text { Odor threshold } \\
(\mathrm{ppm})\end{array}$} & \multicolumn{2}{|c|}{ Odor index } \\
\cline { 3 - 4 } & & AS reactor & BM reactor \\
\hline Hydrogen sulfide & 0.0005 & 2,080 & 138 \\
\hline Methyl mercaptan & 0.0001 & 1,932 & 34 \\
\hline Dimethyl sulfide & 0.0001 & 33 & - \\
\hline Dimethyl disulfide & 0.0003 & 5 & - \\
\hline Odor Unit & - & 4,050 & 172 \\
\hline
\end{tabular}

$\mathrm{H}_{2} \mathrm{~S}$ 가 산화반응에 의해 생분해될 때 산화반응은 광합성세 균과 같은 광독립영양균(Photoautotrophs)과 화학독립영양균 (Chemoautotrophs)에 의해 일어난다. 광합성세균은 이산화탄 소 및 황화수소를 흡수 이용하며, 오염 및 악취의 방지 효과를 나타낸다고 알려져 있다. Table 3에서와 같이 본 연구에서 이 용된 $\mathrm{BM}$ 제제 종균의 pyrosequencing 결과에서도 광합성세 균인 Rhodospirillales 종이 $0.5 \%$ 라는 높은 비율로 존재하였 으며, 이에 $\mathrm{BM}$ 제제 주입에 따라 Odor unit를 상당히 낮출 수 있었던 것으로 해석된다.

기존 연구들에 의하면 $\mathrm{H}_{2} \mathrm{~S}$ 처리에는 Thiobacillus thioparus, Thiobacillus thiooxidans, Chlorobium thiosulfatophlium, Rhodococcus rhodochrous, Ralastorina sp. 등 여러 균들이 이용되고 있으며 $\mathrm{H}_{2} \mathrm{~S}$ 는 미생물에 의하여 호 기, 혐기조건에서 원소상 황(Elemental sulfur, $\mathrm{S}^{\mathrm{O}}$ )으로 산화되 어 유황 입자를 세균 세포 내에 퇴적시키는 형태로 생물학적 으로 제거된다(오, 2004, 서, 2007). 그러나 이러한 균들은 생 장속도가 매우 느리고 생물학적 처리를 위한 정상상태 유지에 어려움이 있는 것으로 알려져 있다. $\mathrm{Kim}$ 등(2010)은 $\mathrm{H}_{2} \mathrm{~S}$ 제 거를 위한 생물학적 탈취 장치 운영 결과 Enterobactor hormaecheis이 다른 황산화균들에 비해 처리 효율면에서 우 수함을 나타내었다고 밝히고 있으며, 또한 넓은 온도와 $\mathrm{pH}$ 범 위, 다양한 농도 범위에서도 높은 생장율을 나타내어 생물학 적 처리에 매우 적합한 미생물임을 시사하였다. 본 연구에서 이용된 $\mathrm{BM}$ 제제 종균에서도 Enterobactor hormaecheis이 동 정되었으며 반응기 운영 시 Enterobactor hormaecheis가 단 독으로 황화합물의 농도를 낮춘 것으로 보기는 어려우나 Enterobactor hormaecheis 등의 균이 복합적으로 시너지효과 를 나타내며 황계열 악취물질의 저감에 기여한 것으로 사료된 다.

\section{4. 결 론}

본 연구에서는 선박오수의 생물학적 처리 시 발생될 수 있 는 악취 문제를 제어하고자 $\mathrm{BM}$ 의 적용을 검토하였다. 이를 위하여 기존의 $\mathrm{SBR}$ 프로세스를 활성슬러지로 운영한 경우와 활성슬러지에 $\mathrm{BM}$ 을 추가 주입하여 운영하여 비교분석한 결 과 다음과 같은 결론을 얻었다.
1. 미생물 관찰 결과 기존의 활성슬러지는 B.subtilis, B.cereus, B.valismortis, B.megaterium 등으로 동정되었으 며, BM 제제는 Pyrosequencing 결과 130종의 다양한 세균 및 효모로 구성되어 있었으며 미생물종의 다양성과 높은 미생물 개체수를 나타내었다.

2. $\mathrm{PCR}-\mathrm{DGGE}$ 기법에 의한 미생물 군집 분석결과 $\mathrm{BM}$ 제 제의 주입으로 슬러지 내 우점종이 악취처리에 유리한 미생물 종으로 전환되는 것을 확인할 수 있었다.

3. $\mathrm{BM}$ 제제의 주입으로 황계열 악취물질의 악취강도를 20 배 가까이 낮출 수 있었다.

4. 또한 이러한 결과는 여타의 시설 추가 없이 기존의 활성 슬러지에 $\mathrm{BM}$ 제제를 주입하는 것만으로 얻을 수 있어 선박 환경에서 매우 편리하게 적용할 수 있을 것으로 판단된다.

5. 향후 선박에서 발생하는 오수에 함유되어 있는 다양한 유해 성분 처리를 위한 $\mathrm{BM}$ 제제의 적용을 검토할 가치가 있 을 것으로 판단된다.

\section{참 고 문 헌}

[1] 김현욱, 이인규, 권순국(2010), "이단 병합 소화조에서 발 생하는 악취유발 화합물에 관한 연구”, 한국환경분석학회 지, Vol. 13, No. 1, pp.40 44

[2] 서용수(2007), “미량 다성분 폭합 악취물질 정량 분석을 통 한 악취 특성 평가”, 부경대학교 학위논문

[3] 안영석, 최원준, 김택준, 김임경, 오광중(2008), “하수슬러 지 탄화물 흡착제를 이용한 혼합 악취 제거”, 대한환경공 학회지, Vol. 30, No. 11, pp.1132 1138

[4] 오성근(2004), "다공성 세라믹 담체 Biofilter를 이용한 유 황계 화합물 단독 및 혼합 악취 제거에 관한 연구”, 우송 대학교 학위논문

[5] 윤덕훈, 강동우, 남기웅(2009), “효모 첨가에 따른 돈분뇨 의 악취제거 및 오염물질 감소 효과”, 한국환경농학회지, Vol. 28, No. 1, pp.47 52

[6] 이영희(2004), “유용미생물을 이용한 환경정화에 관한 연 구”, 경성대학교 학위논문

[7] Assiam, H., Penninckx, M. J and Benlemlih, M.(2007), "Reduction of phenolics content and COD in olive oil mill wastewater by indigenous yeasts and fungi", Microb. and Bio tech., Vol. 23, No. 9, pp.1203 1208 